\title{
Inhibition of rat microsomal lipid peroxidation by the oral administration of D002
}

R. Menéndez,

A.M. Amor, R.M. González, S. Jiménez and R. Más
Center of Natural Products, N ational Center for Scientific Research, Havana, Cuba

\section{Correspondence}

R. Menéndez Soto del Valle Laboratory of Biochemistry Center of Natural Products National Center for Scientific Research P.O. Box 6880

Havana

Cuba

Fax: + 53-7-33-6837

Received May 15, 1998 Accepted September 22, 1999

\section{Abstract}

The effect of D002, a defined mixture of higher primary alcohols purified from bee wax, on in vivo and in vitro lipid peroxidation was studied. The extent of lipid peroxidation was measured on the basis of the levels of thiobarbituric acid reactive substances (TBARS). When D002 (5-100 mg/kg body weight) was administered orally to rats for two weeks, a partial inhibition of the in vitro enzymatic and nonenzymatic lipid peroxidation was observed in liver and brain microsomes. Maximal protection (46\%) occurred at a dose of $25 \mathrm{mg} / \mathrm{kg}$. D002 behaved differently depending on both the presence of NADPH and the integrity of liver microsomes, which suggests that under conditions where microsomal metabolism was favored the protective effect of D002 was increased. D002 $(25 \mathrm{mg} / \mathrm{kg})$ also completely inhibited carbon tetrachloride- and toluene-induced in vivo lipid peroxidation in liver and brain. Also, D002 significantly lowered in a dose-dependent manner the basal level of TBARS in liver (19-40\%) and brain (28-44\%) microsomes. We conclude that the oral administration of D002 $(5,25$ and $100 \mathrm{mg} / \mathrm{kg})$ for two weeks protected rat liver and brain microsomes against microsomal lipid peroxidation in vitro and in vivo. Thus, D002 could be useful as a dietary natural antioxidant supplement. More studies are required before these data can be extrapolated to the recommendation for the use of D002 as a dietary antioxidant supplement for humans.

\section{Introduction}

D002 is a well-defined mixture of higher primary alcohols isolated and purified from bee wax. Triacontanol is its main component, followed by octacosanol, dotriacontanol, hexacosanol and tetracosanol. Tetracontanol is also present as a minor component (1). Previous work has demonstrated a moderate antiinflammatory effect of D002, since oral administration of D002 signifi-

\section{Key words}

- D002

- Higher aliphatic alcohols

- Microsomes

- Lipids

- Peroxidation cantly inhibited the volume of carrageenaninduced exudate and the pellet dry weight of the granuloma (2). Evidence supports that reactive oxygen species appear to be involved in the inflammatory process, including the generation of chemotactic factors and tissue damage (3-6). Thus, some antiinflammatory drugs are thought to exert part of their action by decreasing the reactive oxygen species (7-9).

We report here initial studies directed at 
the investigation of the effect of oral treatment with D002 on lipid peroxidation. We evaluated the effect of D002 on enzymatic and non-enzymatic rat microsomal peroxidation in liver and brain in vitro. We also studied the action of D002 against in vivo lipid peroxidation by determining its effects on carbon tetrachloride $\left(\mathrm{CCl}_{4}\right)$ - and tolueneinduced lipid peroxidation in liver and brain.

\section{Material and Methods}

\section{Material}

Technical grade D002 (92\% purity by gas chromatography) was supplied by the Department of Chemistry, Center of Natural Products (Havana, Cuba). The batch composition was as follows: $26.63 \%$ triacontanol, $17.49 \%$ octacosanol, $16.95 \%$ dotriacontanol, $15.34 \%$ hexacosanol, $13.24 \%$ tetracosanol and $2.23 \%$ tetratriacontanol. Thiobarbituric acid (TBA) and 1,1,3,3-tetramethoxypropane (TMP) were obtained from Sigma Chemical Co. (St. Louis, MO, USA). Nicotinamide adenine dinucleotide phosphate (NADPH) was obtained from Boehringer Ingelheim Ltd., London, UK. $\mathrm{CCl}_{4}$, ascorbate and toluene were purchased from Fluka (Buchs, Zwitzerland). All other chemicals were of the best available grade. Male Wistar rats were purchased from the Centro Nacional para la Producción de Animales de Laboratorio (CENPALAB, Havana, Cuba).

\section{In vitro experiments}

Animals and treatment. Wistar rats (180$200 \mathrm{~g}$ ) were used throughout the study. D002 was suspended in a $2 \%$ Tween 20 /water vehicle and administered orally $(5,25$ and $100 \mathrm{mg} / \mathrm{kg}$ ) for two weeks by gastric gavage $(1 \mathrm{ml} / 200 \mathrm{~g})$. A control group received an equivalent volume of the vehicle.

Preparation of microsomes. After treatment, rats were anesthetized and the livers were perfused with ice cold $\mathrm{KCl}(1.15 \% \mathrm{w} /$ v). Livers were homogenized in $250 \mathrm{mM}$ sucrose and microsomes were prepared by differential centrifugation as described previously (10). Brains were removed and homogenized in $40 \mathrm{mM}$ Tris buffer, $\mathrm{pH}$ 7.4. Microsomes were obtained in the same manner as for liver microsomes. The microsomal protein concentration was determined by a modification of the Lowry procedure (11).

Assay for lipid peroxidation. Lipid peroxidation of liver microsomes was initiated by the addition of either a) $25 \mu \mathrm{M} \mathrm{FeSO}$, $100 \mu \mathrm{M}$ ascorbate and $10 \mathrm{mM} \mathrm{KH}_{2} \mathrm{PO}_{4}$, or b) $2 \mu \mathrm{M} \mathrm{FeCl}_{3} / 200 \mu \mathrm{M}$ ADP (previously complexed) and $200 \mu \mathrm{M}$ NADPH according to Ruiz-Lerrea et al. (12). When ascorbate system was used, liver microsomes were heat inactivated before being added to the incubation mixture. Microsomal lipid peroxidation of brain was performed according to Cini et al. (13) using microsomes instead of crude homogenates. Microsomes were incubated at $37^{\circ} \mathrm{C}$ for $60 \mathrm{~min}$ with no addition (spontaneous) or after the addition of a free radical-generating system $\left(100 \mu \mathrm{M} \mathrm{FeCl}_{2}\right)$. Lipid peroxidation was monitored by the formation of thiobarbituric acid reactive substances (TBARS) according to Ohkawa et al. (14). After extraction with n-butanol and pyridine $(15: 1 \mathrm{v} / \mathrm{v})$, the amount of TBARS formed was determined by measuring the absorbance of the organic layer at $532 \mathrm{~nm}$. In parallel TMP was used as an external standard. Results are reported as nmol malondialdehyde (MDA)/mg microsomal protein.

\section{In vivo experiments}

Animals and treatment. Male Wistar rats were randomly divided into five groups (10 animals/group) and were given free access to standard laboratory diet and water. Two control groups received vehicle alone and three treated groups received 5, 25 and 100 $\mathrm{mg} \mathrm{D002/kg}$. For $\mathrm{CCl}_{4}$-induced liver peroxidation, food was withdrawn 12-14 h before $\mathrm{CCl}_{4}$ administration but after dosing rats had 
Table 1 - Effects of oral administration of D002 on TBARS accumulation initiated by Fe $\mathrm{Fe}^{3+} / \mathrm{ADP} / \mathrm{NADPH}$ in liver native microsomes (enzymatic system) and by $\mathrm{Fe}^{2+} /$ ascorbate in liver denatured microsomes (non-enzymatic system).

TBARS are reported in terms of malondialdehyde (MDA). Data are reported as means \pm SD for 10 rats in each group. $* \mathrm{P}<0.05$ compared to control (Mann-Whitney U-test).

\begin{tabular}{lllllc}
\hline Treatment & \multicolumn{2}{c}{ Enzymatic system } & & \multicolumn{2}{c}{ Non-enzymatic system } \\
\cline { 2 - 3 } & MDA (nmol/mg) & Inhibition (\%) & & MDA (nmol/mg) & Inhibition (\%) \\
\hline Control & $16.11 \pm 1.45$ & - & & $17.65 \pm 1.01$ & - \\
D002 $(5 \mathrm{mg} / \mathrm{kg})$ & $12.47 \pm 1.35^{*}$ & 23 & & $15.70 \pm 1.03$ & 11 \\
D002 $(25 \mathrm{mg} / \mathrm{kg})$ & $11.01 \pm 1.01^{*}$ & 32 & & $14.80 \pm 1.43$ & 16 \\
D002 $(100 \mathrm{mg} / \mathrm{kg})$ & $10.60 \pm 1.04^{*}$ & 34 & & $16.43 \pm 1.35$ & 17
\end{tabular}

free access to food and water. All groups received $1 \mathrm{ml} / \mathrm{kg} \mathrm{CCl}$ in $10 \%$ corn oil (v/v) by intraperitoneal (ip) injection, except the negative control group which received corn oil ip $(1 \mathrm{ml} / \mathrm{kg})$. Toluene-induced brain damage was performed according to Hanna et al. (15) and Mattia et al. (16). Rats were injected with a single dose of toluene $(1.5 \mathrm{~g} /$ $\mathrm{kg}$ ) ip. The negative control group was injected ip with comparable volumes of normal saline. All animals were sacrificed by decapitation $24 \mathrm{~h}$ after $\mathrm{CCl}_{4}$ injection and $4 \mathrm{~h}$ after toluene injection. Liver and brain microsomes were prepared as described for the in vitro experiments.

\section{Statistical analysis}

Data are reported as means $\pm \mathrm{SD}$. Statistical analysis was performed by the MannWhitney U-test and $\mathrm{P}<0.05$ was considered to be statistically significant.

\section{Results}

Treatment of rats with D002 resulted in partial inhibition of liver microsome lipid peroxidation. As shown in Table 1, oral administration of D002 partially prevented the accumulation of TBARS in vitro in liver microsomes in a dose-dependent manner. When the reduced nicotinamide coenzyme was present (enzymatic system) D002 caused
Table 2 - Effect of oral administration of D002 on TBARS accumulation in brain microsomes after incubation with $\mathrm{FeCl}_{2}(100 \mu \mathrm{M})$.

TBARS accumulation is reported in terms of malondialdehyde (MDA). Data are reported as means \pm SD for 8 rats in each group. Values were determined by subtracting spontaneous lipid peroxidation from Fe-induced lipid peroxidation. *P $<0.05$ compared to control (Mann-Whitney U-test).

\begin{tabular}{lcc}
\hline Treatment & $\begin{array}{c}\text { MDA } \\
(\mathrm{nmol} / \mathrm{mg})\end{array}$ & $\begin{array}{r}\text { Inhibition } \\
(\%)\end{array}$ \\
\hline Control & $5.79 \pm 0.54$ & - \\
D002 $(5 \mathrm{mg} / \mathrm{kg})$ & $4.12 \pm 0.77^{*}$ & 28.8 \\
D002 $(25 \mathrm{mg} / \mathrm{kg})$ & $3.10 \pm 0.75^{*}$ & 46.4 \\
D002 $(100 \mathrm{mg} / \mathrm{kg})$ & $3.16 \pm 0.29^{*}$ & 45.2
\end{tabular}

a partial inhibition of lipid peroxidation (apparent maximal 32\% inhibition after administration of $25 \mathrm{mg} / \mathrm{kg}$ ). Additional experiments were performed with heat-treated microsomes. Analysis of TBARS accumulation after the administration of similar doses of D002 revealed that lipid peroxidation was partially depressed but to a lesser extent when compared with native microsomes (apparent maximal $16 \%$ inhibition at $25 \mathrm{mg}$ D002/kg) (Table 1).

We also tested the ability of D002 to inhibit TBARS accumulation by brain microsomes. As shown in Table 2, TBARS are formed in appreciable amounts by brain microsomes after $30 \mathrm{~min}$ in the presence of 100 $\mu \mathrm{M} \mathrm{FeCl}$. D002 was able to inhibit iron- 
Table 3 - Effect of oral administration of D002 on basal TBARS levels in liver and brain microsomes.

TBARS are reported in terms of malondialdehyde (MDA). Data are reported as means \pm SD for 10 rats in each group. $* \mathrm{P}<0.05$ compared to control (Mann-Whitney U-test).

\begin{tabular}{lcccc}
\hline Treatment & $\begin{array}{c}\text { Liver MDA } \\
\text { (nmol/mg protein) }\end{array}$ & $\begin{array}{c}\text { Inhibition } \\
(\%)\end{array}$ & $\begin{array}{c}\text { Brain MDA } \\
(\text { nmol/mg protein) }\end{array}$ & $\begin{array}{c}\text { Inhibition } \\
(\%)\end{array}$ \\
\hline Control & $1.88 \pm 0.19$ & - & $1.99 \pm 0.23$ & - \\
D002 $(5 \mathrm{mg} / \mathrm{kg})$ & $1.51 \pm 0.24$ & 19.68 & $1.43 \pm 0.18$ & 28.14 \\
D002 $(25 \mathrm{mg} / \mathrm{kg})$ & $1.15 \pm 0.28^{*}$ & 38.82 & $1.10 \pm 0.24^{*}$ & 44.72 \\
D002 $(100 \mathrm{mg} / \mathrm{kg})$ & $1.11 \pm 0.30^{*}$ & 40.95 & $1.13 \pm 0.08^{*}$ & 43.72
\end{tabular}

Table 4 - Effect of oral administration of D002 on in vivo $\mathrm{CCl}_{4}$-induced lipid peroxidation by liver microsomes.

Lipid oxidation was measured in terms of malondialdehyde (MDA). Data are reported as means \pm SD for 10 rats in each group. $* \mathrm{P}<0.05$ compared to control group. $* * \mathrm{P}<0.05$ compared to control $+\mathrm{CCl}_{4}$ group (MannWhitney U-test).

\begin{tabular}{lcc}
\hline Treatment & $\begin{array}{c}\text { MDA } \\
(\mathrm{nmol} / \mathrm{mg} \\
\text { protein) }\end{array}$ & $\begin{array}{c}\text { Inhibition } \\
(\%)\end{array}$ \\
\hline Control & $1.94 \pm 0.67$ & - \\
Control $+\mathrm{CCL}_{4}$ & $3.90 \pm 0.65 *$ & - \\
D002 $(5 \mathrm{mg} / \mathrm{kg})+\mathrm{CCL}_{4}$ & $2.33 \pm 0.67 * *$ & 80.10 \\
$\mathrm{D} 002(25 \mathrm{mg} / \mathrm{kg})+\mathrm{CCL}_{4}$ & $1.73 \pm 0.39 * *$ & 100 \\
$\mathrm{D} 002(100 \mathrm{mg} / \mathrm{kg})+\mathrm{CCL}_{4}$ & $1.67 \pm 0.40^{* *}$ & 100
\end{tabular}

Table 5 - Effect of oral administration of D002 on in vivo toluene-induced lipid peroxidation by brain microsomes.

Lipid oxidation was measured in terms of malondialdehyde (MDA). Data are reported as means \pm SD for 10 rats in each group. * $\mathrm{P}<0.05$ compared to control group. **P<0.05 compared to control + toluene group (Mann-Whitney U-test).

\begin{tabular}{lcc}
\hline Treatment & $\begin{array}{c}\text { MDA } \\
(\mathrm{nmol} / \mathrm{mg} \\
\text { protein) }\end{array}$ & $\begin{array}{c}\text { Inhibition } \\
(\%)\end{array}$ \\
\hline Control & $1.32 \pm 0.20$ & - \\
Control + toluene & $3.95 \pm 0.19^{*}$ & - \\
D002 $(5 \mathrm{mg} / \mathrm{kg})+$ toluene & $1.99 \pm 0.22^{* *}$ & 71.61 \\
D002 $(25 \mathrm{mg} / \mathrm{kg})+$ toluene & $1.03 \pm 0.21^{* *}$ & 100 \\
D002 $(100 \mathrm{mg} / \mathrm{kg})+$ toluene & $1.04 \pm 0.19^{* *}$ & 100
\end{tabular}

induced lipid peroxidation in brain microsomes since TBARS accumulation was significantly decreased after D002 treatment at doses of 5, 25 and $100 \mathrm{mg} / \mathrm{kg}$. D002 provided only partial protection, since a maximal $46 \%$ inhibition was observed after adminis-

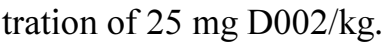

The antioxidant action of D002 was further demonstrated by in vivo experiments, which showed that oral administration of D002 for 2 weeks significantly lowered in a dose-dependent manner the basal level of lipid peroxidation in liver and brain microsomes (Table 3 ). Table 4 shows the effect of various doses of D002 administered for 2 weeks prior to the injection of $\mathrm{CCl}_{4}$. D002 treatment significantly inhibited the effect of $\mathrm{CCl}_{4}$, which occurred at doses of 5,25 and $100 \mathrm{mg} / \mathrm{kg}$. In addition, D002 prevented the toluene-induced lipid peroxidation in brain (Table 5). Lipid peroxidation by brain microsomes (TBARS) isolated from rats injected $i p$ with toluene was significantly higher than that observed in rats injected with saline. The stimulation of lipid peroxidation produced by toluene was significantly inhibited by D002 administration, since doses of 25 and $100 \mathrm{mg} / \mathrm{kg}$ fully inhibited TBARS accumulation.

\section{Discussion}

The present study demonstrated that the oral administration of D002 partially inhibited the in vitro and in vivo lipid peroxidation 
in liver and brain microsomes in a dosedependent manner. Microsome fractions isolated from liver and brain of rats treated with several doses of D002 were more resistant to lipid peroxidation than those isolated from control rats. The maximal effect occurred at a dose of $25 \mathrm{mg} / \mathrm{kg}$, with no additional protection observed with $100 \mathrm{mg} / \mathrm{kg}$. D002 behaved differently depending on both the presence of NADPH and the integrity of liver microsomes. In studies with denatured microsomes, D002 produced lower protection when compared with native microsomes incubated with NADPH. At present we cannot explain the mechanism underlying these differences, but it seems clear that under conditions where microsome metabolism was favored, the protective effect of D002 was also increased.

We also examined the effect of D002 on in vivo lipid peroxidation. $\mathrm{CCl}_{4}$-induced liver microsome lipid peroxidation was used, since the hepatotoxicity of this solvent has been reported to be related to lipid peroxidation $(17,18)$. Also, we studied the effect of D002 on toluene-induced lipid peroxidation in brain microsomes, since toluene is a neurotoxic chemical that acts by increasing the generation of reactive oxygen species in brain (16). When the ability of D002 to inhibit TBARS generation in vivo after both chemicals was tested, an inhibition of TBARS generation was observed. This indicated that D002 not only protected microsomes against in vitro lipid peroxidation but also against in vivo peroxidation. As observed in the in vitro models, the maximal effect was attained at doses of $25 \mathrm{mg} / \mathrm{kg}$. The high degree of protection against oxidative stress in brain exerted by D002 might be biologically relevant. In this regard, it should be considered that brain is highly susceptible to peroxidative damage because of its high degree of unsaturated fatty acids in relation to its antioxidant levels and its high oxygen consumption (19-22).

It is known that in mammals superoxide dismutase and peroxide-metabolizing enzymes, catalase and glutathione peroxidase represent an efficient defense system against hazards of lipid peroxidation. The data presented here also indicate that D002 decreased the basal level of TBARS in liver and brain. This result, together with differences in the degree of protection against lipid peroxidation in vitro when comparing the enzymatic model and the denaturalized microsomes, suggests that an effect on the defense enzyme system should not be ruled out. Therefore, this possibility should be considered in future investigations.

In conclusion, the above results show that oral administration of D002 $(5,25$ and $100 \mathrm{mg} / \mathrm{kg}$ ) for two weeks protects rat liver and brain microsomes against in vitro and in vivo microsomal lipid peroxidation as assessed by measured TBARS levels. More studies are required before these data can be extrapolated to the recommendation for the use of D002 as a dietary antioxidant supplement for humans.

\section{References}

1. Magraner J, Laguna A, Más R, Carbajal D, Arruzazabala L, Díaz M, Molina V \& Valdés S (1995). Una mezcla natural compuesta por alcoholes alifáticos primarios obtenidos de la cera de abejas para el tratamiento de las úlceras gástricas y duodenales, que presenta también actividad antinflamatoria. Patente C.I: AGI/ C31/045,35/64, Cuba.

2. Carbajal D, Molina V, Valdés $S$,
Arruzazabala L \& Más R (1999). Antiinflammatory effects of higher primary alcohols from bee wax. Prostagladins, Leukotrienes and Essential Fatty Acids (in press).

3. Halliwell B, Gutteridge J MC \& Blake D (1985). Metal ions and oxygen radicals reactions in human inflammatory joint disease. Philosophical Transactions of the Royal Society of London, 311: 659-671.
4. Dowling EJ, Symons AM \& Parke DV (1986). Free radicals production at the site of an acute inflammatory reaction as measured by chemiluminescence. Agent and Actions, 19: 203-207.

5. Weiss SJ (1986). Oxygen ischemia and inflammation. Acta Physiologica Scandinavica, 548 (S): 9-37.

6. Babior BM (1978). Oxygen dependent microbial killing by phagocytes. New Eng- 
land J ournal of Medicine, 298: 721-725.

7. Aruoma O \& Halliwell B (1988). The ironbinding and hydroxyl radical scavenging action of antiinflammatory drugs. Xenobiotica, 18: 459-470.

8. Hurst NP, French JK, Bel AL, Nuki G, O'Donell M, Betts WH \& Cleland LG (1986). Differential effects of mecrapine, chloroquine and hydroxychloroquine on superoxide anion generation phospholipid methylation and arachidonic acid release by human blood monocytes. Biochemical Pharmacology, 35: 3083-3089.

9. Oyanagui $Y$ (1978). Inhibition of superoxide anion production in non stimulated guinea pig peritoneal exudate cells by antiinflammatory drugs. Biochemical Pharmacology, 27: 777-782.

10. Fraga $V$, Menéndez R, Amor A, González R, J iménez S \& Más R (1997). Effect of policosanol on in vitro and in vivo microsomal liver peroxidation. Archives of Medical Research, 28: 355-360.

11. Markwell MA, Haas SM, Beiber LL \& Tolbert NE (1987). A modification of the Lowry procedure to simplify protein determination in membrane and lipoprotein samples. Analytical Biochemistry, 87: 206209.

12. Ruiz-Lerrea MB, Leal AM, Liza M, Lacort $M \&$ Groot $H$ (1994). Antioxidant effects of stradiol and 2-hydroxyestradiol on ironinduced lipid peroxidation of rat liver microsomes. Steroids, 59: 383-387.

13. Cini $M$, Fariello RG, Bianchetti $A \&$ M oretti A (1994). Studies on lipid peroxidation in the rat brain. Neurochemical Research, 19: 283-288.

14. Ohkawa H, Ohishi N \& Yagi K (1979). Assay for lipid peroxides in animal tissues by the thiobarbituric acid reaction. Analytical Biochemistry, 95: 351-358.

15. Hanna AN, Sharma HM, Kauffman EM \& Newman HAl (1994). In vitro and in vivo inhibition of microsomal lipid peroxidation by MA-631. Pharmacology, Biochemistry and Behavior, 48: 505-510.

16. Mattia CJ , LeBel CP \& Bondy SC (1991). Effects of toluene and its metabolites on cerebral reactive oxygen species. Biochemical Pharmacology, 42: 879-882.

17. Recknagel RO, Glende EA, Dolak JA \& Waller RL (1989). Mechanism of $\mathrm{CCl}_{4}$ toxicity. Pharmacology and Therapeutics, 43:
134-154.

18. Tomasi A, Albano S, Banni S, Botti F, Cerongiu F, Dessi MA, Lannone A, Vanini V \& Dianzani M (1987). Free-radical metabolism of carbon tetrachloride in rat liver mitochondria. Biochemical J ournal, 240: 313-317.

19. Braughler J M (1989). Central nervous system trauma and stroke. Biochemical consideration for oxygen radicals formation and lipid peroxidation. Free Radical Biology and Medicine, 6: 289-301.

20. Halliwell B \& Gutteridge J MC (1985). Oxygens radicals and the nervous system. Trends in Neurosciences, 8: 22-26.

21. Lissi EA, Caceras T\& Videla IA (1986). Visible chemiluminescence from rat brain homogenates undergoing autooxidation. 1. Effects of additives and products accumulation. Free Radical Biology and Medicine, 2: 63-69.

22. Ratty A \& Das NP (1986). Lipid peroxidation in the rat brain mitochondria in the presence of ascorbic acid. International Research Communication System. Medical Science: Biochemistry, 14: 815-816. 